\title{
Happy people: Who are they? A pilot indigenous study on conceptualization of happiness in Vietnam
}

\begin{abstract}
BACKGROUND
Happiness or subjective well-being has been a popular subject of psychological research in the past decades. Besides certain mutual agreement on the definition of happiness, most of the authors also believe that for each individual, happiness or subjective well-being is significantly influenced by the culture he or she belongs to. Therefore, local definitions of happiness formed in specific cultural contexts need to be clarified and developed systematically. This is the theoretical starting point for us to conduct this preliminary research.
\end{abstract}

\section{PARTICIPANTS AND PROCEDURE}

Research subjects including 58 Vietnamese were selected as convenient samples, living and working in Hanoi. The subjects' average age is $23.90(S D=2.48)$. Data were collected via in-depth interview. The data analysis was performed by thematic analysis based on the procedures proposed by Braun and Clarke, then processed with SPSS 22.0 for quantitative assessment.

\section{RESULTS}

The results of data analysis indicate the following criteria to consider an individual as being happy or unhappy: 1) material living standard;2) health and outlook; 3) selfactualization; 4) community belonging; 5) social relationships; 6) relationships with other family members; 7) positive psychological qualities; 8) personal safety; and 9) some other external factors. Of these, positive psychological qualities were chosen with the highest frequency, followed by self-actualization, social relationships, and relationships with other family members. The results of quantitative analysis also show a statistically significant difference in terms of positive psychological qualities by gender.

\section{CONCLUSIONS}

The research results might be explained from a socio-cultural perspective and provide a scientific basis for largescale studies on this topic in Vietnam.

KEY WORDS

happiness; thematic analysis; Vietnamese people

ORGANIZATION - University of Social Sciences and Humanities - Vietnam National University, Hanoi, Vietnam AUthors' CONTRibutions - A: Study design - B: Data collection - C: Statistical analysis - D: Data interpretation . E: Manuscript preparation · F: Literature search · G: Funds collection

CORRESPonding AUthor - Linh Thi Trinh, Ph.D., University of Social Sciences and Humanities (VNU-Hanoi), 336 Nguyen

Trai, Thanh Xuan, Hanoi, Vietnam, e-mail: anhlinh_huong@yahoo.com

to Cite this ARticLE - Trinh, L. T., \& Khanh Ha, T. T. (2019). Happy people: Who are they? A pilot indigenous study on

conceptualization of happiness in Vietnam. Health Psychology Report. https://doi.org/10.5114/hpr.2019.88527

RECEIVED 17.07.2019 • REVIEWED 14.09.2019 • ACCEPTED 14.09.2019 • PUBLISHED 07.10.2019 


\section{BACKGROUND}

Happiness is not only a core value but also a continuous target throughout a person's lifetime, as well as of the society. Throughout the course of history, happiness has always been the aspiration of humankind. Since ancient times, people have always wondered what contributes to a good life and a sense of happiness. People's approach to happiness plays an extremely important role in spiritual life in general, and ethical
Linh Thi Trinh, Ha Truong Thi Khanh life in particular. Acting as one of the spiritual foundations that helps people develop their ideals, goals, and attitudes, it is also a measure of direction for people to establish an understanding about right, wrong, dignity, and other various human concepts. Consequently, for a major course of history, many sciences (e.g., ethics, theology, politics, economics, or psychology) have been trying to find answers to this issue (see Argyle, 2001; Diener, 1984; Veenhoven, 1984, 2003). However, research on happiness/subjective well-being only began at the beginning of the $20^{\text {th }}$ century. In 1925 , Flugel triggered this research trend with a study of human moods, which involved recording events and emotional reactions of human beings. During the 1930s to the 1940s, researchers on happiness and life satisfaction focused on the question "Which level of happiness do you feel?" with various answers ranging from "very happy" to "unhappy" (Diener, Suh, Lucas, \& Smith, 1999; Diener, 2009; Diener \& Tov, 2007).

In recent decades, happiness/subjective well-being has become one of the most popular research topics in psychology in general (Diener et al., 1999), and one of the most crucial topics in positive psychology in particular (Seligman \& Csikszentmihalyi, 2000). Happiness is a complex and diverse concept that is difficult to define. It can mean pleasure, life satisfaction, positive emotions, a meaningful life, or a feeling of contentment. Despite this, happiness can be measured. For example, in a survey of college students from 17 countries, Diener (2000) found that happiness and life satisfaction were both rated well above neutral on the level of importance (compared to that of money) in every country (see Diener, 2009). Additionally, according to Lu (2005), quantitative studies on happiness reveal certain agreement in the understanding of happiness. Firstly, happiness is generally defined as a predominance of positive over negative effects and as satisfaction with life as a whole (Argyle, Martin, \& Crossland, 1989; Diener, 1984). Secondly, happiness tends to be generalized as a trait rather than an emotional state (Veenhoven, 1994). Thirdly, happiness is generated from several external "factors" (Andrews \& Withey, 1976; Campbell, Converse, \& Rodgers, 1976). Finally, happiness is a culture-based concept. Also, Haybron (2013) listed five factors which are considered as the roots of happiness: security, outlook, autonomy, relationships (family, friends, communities), and skilled and meaningful activity.
In Vietnam, happiness is not an unknown concept. The construct of happiness is included in the country's motto: "Independence - Freedom - Happiness". Therefore, in practice, happiness for citizens in Vietnam is inclusively regarded as a prime target of every major policy and direction of the Party and the Government. In 2014, one year after the International Day of Happiness $\left(20^{\text {th }}\right.$ March) was founded, Vietnam organized official activities which aimed at celebrating the event with the theme "Love and Share". Since then, the International Day of Happiness has been celebrated annually. However, it seems that research studies on happiness have not received proper attention from the academic community in Vietnam. With respect to research on happiness in Vietnam, two trends are observed: research studies on happiness based on individual experiences, which are quite subjective, and survey-based research studies. Examples of the first trend include: "Happiness, power, and greed" (Nguyễn Tường Bách, 2012), "Development and happiness" (Nguyễn Văn Thọ, 2012), and "Does knowledge bring happiness?” (Nguyễn Văn Trọng, 2012). Regarding the second trend, one of the first studies about life satisfaction was conducted by Hoàng Bá Thịnh and his colleagues (Hoàng Bá Thịnh, 2012; Dương Thị Thu Hương, 2012; Nguyễn Thị Vân Hạnh, 2013). This research was conducted in four provinces and cities, comprising Hanoi, Hai Duong, Binh Duong, and Ho Chi Minh City. From this research, the results showed that Vietnamese people were relatively satisfied with their life and the relationships of parents - children, marriage, family, and offspring - hold the most important role in one's happiness. Additionally, expenses, education levels, incomes, and infrastructure were ranked as the least influential factors among levels of happiness. In accordance with the second research trend, Rogoza, Truong, Różycka-Tran, Piotrowski, and Żemojtel-Piotrowska (2018) conducted research related to the psychometric properties of the Mental Health Continuum-Short Form (MHC-SF) in the Asian population. The results confirmed the validity of this scale in Vietnamese adolescents. Recently, another notable study was that of Markussen, Fibæk, Tarp, and Tuan (2018), which examined "happy farmers" in rural areas of Vietnam. In this research, happiness was measured via a single item: 'Taking all things together, would you say you are: (1) very pleased with your life; (2) rather pleased with your life; (3) not very pleased with your life; (4) not at all pleased with your life?'. The results of this study showed that in general, respondents were fairly satisfied with their life. Finally, a nation-level scientific project, chaired by Lê Ngọc Văn (2018), was related to the happiness of Vietnamese people. In this project, levels of happiness in Vietnamese were measured with quantitative tools for three indicators, including: satisfaction with materials - economic conditions and natural environment; satisfaction with society - family relationships; and 
self-satisfaction. Therefore, it can be seen that the second trend in Vietnam has been reviewed from a more scientific perspective. Nevertheless, the authors seemingly still lacked a clear boundary between satisfaction and well-being. As a result, the measurement instruments either did not truly reflect the nature of happiness, excessively concentrated on quantitative data, or were simply adapted from international measurement instruments.

The vast majority of happiness/subjective well-being instruments have been developed in high-income Western countries (e.g., US, Europe), and "far less information is available elsewhere" (Selin \& Davey, 2012 , p. 1). From a culturally psychological perspective, a review of world research allows us to assert that self-concept changes from one culture to another (Triandis, 1994, 1995; Mashaba, 1996; Christopher, 1999; Kareem \& Littlewood, 2000; Markus \& Kitayama, 1991, 1998; Uchida, Ronasakkunkit, \& Kitayama, 2004; Uchida \& Ogihara, 2012). Stated differently, cultures set up various aspects of self, such as the way people perceive one another. Markus and Kitayama (1998) have mentioned that "the communities, societies, and cultural contexts in which people participate provide the interpretive frameworks - the theories, images, concepts, and narratives as well as the means, practices, and patterns of behavior - by which people make sense" (p. 66). Generating from individualistic cultures, Western-American theories of happiness or subjective well-being have been developed mainly on such a cultural basis. As a result, in these cultures, individuals are encouraged to seek and affirm their personal qualities. Despite their importance, social relationships are built on the basic assumption of individual independence and motivated by individual striving. Therefore, happiness tends to be associated with personal achievement. Meanwhile, contrary to the Western perspective, Asian culture views the self as being flexibly connected and committed to mutual relationships. Moreover, social customs, institutions, and mass media in Asia mostly place the self in the context of human relationships, focusing on roles, status, and/or membership in groups (Tafarodi, Lang, \& Smith, 1999). This interdependence is the focal point of emotion, thinking and motivation for people in these cultures. The boundary between individuals and others in Asian cultures, therefore, is not clear and is invariably compromised through social interactions. Individuality is defined based on the basic view of the interdependence among people involved. As a result, Asian cultures especially care about the recognition and evaluation of oneself in relation to others and the social groups that they belong to. Meanwhile, a remarkable feature noted in research literature is that even when studies are crosscultural, they usually involve applying measures derived from Western cultural traditions and comparing results from different nations within a priori
Western theoretical frameworks (Lu, 2012). As mentioned above, the value one places on happiness differs across cultures; while collectivists may prioritize duty and obligation over personal happiness, it is uncertain to what extent previous findings are relevant in non-Western countries such as Vietnam. Markus and Kitayama (1991) have noted, "people in different cultures have strikingly different constructs of self, of others, and of the interdependence between the two. These construals can influence, and in many cases determine the very nature of individual experience, including cognition, emotion, and motivation" (p. 224). In other words, the Western concept of subjective well-being should not be imposed on other cultures; instead, local concepts of subjective wellbeing formed in specific cultural contexts should be clarified and developed systematically. As stated by $\mathrm{Lu}$ (2005), the efforts of Western authors in defining happiness via determining components/elements of subjective well-being resulted in limited explanation of the nature and meaning of happiness, or belief of happiness in diversified cultures. This is perhaps why Lu and Gilmour (2006) found four difference in Chinese conceptions of happiness that both individuals and social-oriented aspects emphasized: personal accountability, explicit pursuit, role obligations and dialectical balance. Despite the above, the question remains: Is the Vietnamese view of happiness similar to Western concepts? Due to the lack of research in this area we considered this question.

\section{CHOICE OF METHODOLOGY}

Despite the fact that most humanities and social sciences studies in general, and psychological studies in particular, are conducted with quantitative methodology, Frost (2011) showed that qualitative research methodology in psychology is now well established. It has moved from the margin to the mainstream in psychology research in the UK, and many other researchers and writers attest to its widespread use elsewhere. The use of qualitative assessment methods, such as open-ended questions, provides information about the participants' perceptions, views and beliefs in their own terms, in contrast to using other researchers' definitions and categories, which is typical of quantitative inquiries (Denzin \& Lincoln, 2000). As mentioned by Patton (1990), a truly openended question "allows the person being interviewed to select from that person's full repertoire of possible responses. (...) One of the things the evaluator is trying to determine is what dimensions, themes, and images/words people use among themselves to describe personal feelings, thoughts, and experiences" (p. 296). This methodology allows free expression of individual comments and opinions of the interviewees and minimizes the influence of researchers' viewpoints. In ad-
Happy people: Who are they? 
Linh Thi Trinh, Ha Truong Thi Khanh dition, Patton also confirms that qualitative methods have a particularly important advantage in the sense that qualitative data can be transferred into quantitative data for research purposes. On such a basis, collected information can be deployed on a large number of subjects. Additionally, Glaser and Strauss (1967) believe that qualitative information can help develop and expand theoretical frameworks, by taking the researcher into the real world, so that the results are grounded in the empirical perspective.

In this study, through qualitative analysis of openended questions, we investigated how people defined happiness in their own terms. The purpose of the study was to gain new insights into the Vietnamese people's definition of happiness. This study is considered a first step in constructing a psychometrically reliable and valid scale designed to measure the level of happiness in Vietnamese people.

\section{PARTICIPANTS AND PROCEDURE}

Because of challenges in conducting qualitative research on a large scale in Vietnam, we decided to constrain the age range. We only focused on the subjects at the early stage of adult age (see below) because this group makes up the highest percentage of the Vietnam population. In terms of socio-historical aspects, this target group is not so old and strongly influenced by the traditional standards and values of former Vietnamese society. At the same time, it is not too young to miss any experiences in the traditional standards and values. In terms of psychological development, this population group has mature personality and active participation in the job market. In this age range, many people might have been married. Therefore, collectively, this age group is experienced enough to have personal opinions of happiness. Based on this criterion, the final samples comprised 58 participants with the age range from 20 to 31 years old $(M=23.90, S D=2.49)$, of which females accounted for $60.30 \%$ and males made up $39.70 \%$. $22.20 \%$ had a vocational or college diploma and the rest had university degrees. All of the participants were living and working in Hanoi, Vietnam.

\section{MEASUREMENT}

A questionnaire including seven questions was delivered to all participants. Four items were open-ended questions, including two questions about happy/ unhappy people and two questions about the things in life with which they were most satisfied/dissatisfied. For the purpose of this paper, the focus is on the question regarding happiness. Firstly, the participants were invited to define happiness in their own words via the question: "According to you, what kind of person can be considered as being happy?". They were also requested: "Please list five types of happy persons", followed by the request "For each type, please specify detailed rationales".

Additionally, the questionnaire comprises three close-ended questions to collect information about the socio-demographic data of the population (e.g., age, gender, and educational level).

\section{PROCEDURE}

Data were gathered from a convenience sample of subjects who were at the early stage of adult age. Coding of qualitative data obtained from open-ended questions about happiness was implemented with the six steps proposed by Braun and Clarke (2006), including: 1) familiarizing with the data; 2) generating initial codes; 3) searching for themes; 4) reviewing themes; 5) defining and naming themes; and 6) producing the report.

Following this process, during several meetings, we determined a coding system for the open-ended questions. In many cases, responding options for open-ended question could be categorized within the life domain (e.g., living conditions, social relationships, family relationships, health). However, some additional categories needed to be created because participants often provided purely psychological definitions of happiness, without any reference to specific daily contexts. The categories reflected the main constructs developed in the hedonic and eudaimonic perspectives, such as:

- Self-actualization (e.g., following personal passions, doing the things one wants, affirming the self, etc.);

- Personal safety (e.g., stabilized jobs to ensure life, shelters to settle down, knowledge to be independent from others);

- Positive psychological qualities (e.g., optimistic, fun, honest, free-minded, humorous, empathetic, be inclined to do well, be aspirational, and selfbalanced).

There were several comments on happiness that were totally irrelevant to the aspects of life as well as the psychological features mentioned above. These are temporarily recorded as "other external factors" (e.g., "encountering a surprise", "being lucky", "reading a funny story").

In the final coding system, answers were coded into nine categories for the definition of happy people. Particularly, 294 codes were obtained for this definition. Any questions, doubts or incongruence regarding the process of coding were discussed between the researchers and a consensus was reached.

After all the answers provided by the participants were coded, the data were transferred into and processed by SPSS, version 22.0 for the purpose of quantitative research. 


\section{RESULTS}

All participants clearly shared their opinions about types of happy people. In other words, no participants considered happiness as a vague and indescribable concept. The results of thematic analysis show that a happy person is defined with following nine aspects: 1) Positive psychological qualities; 2) Self-actualization; 3) Social relationships; 4) Relationships with other family members; 5) Living conditions; 6) Health and outlook; 7) Community belonging; 8) Personal safety; and 9) Some other external factors.

The data in Figure 1 indicate that $24.83 \%$ of the answers reflected the belief that a happy person possesses positive psychological qualities. This was followed by self-actualization and positive social relationships; positive relationships with other family members are also considered as one factor that brings happiness from the respondents' viewpoint. Thus, it can be seen that according to the surveyed participants, happiness is determined mainly against positive psychological qualities and self-actualization. These two factors count for $44.22 \%$ of the responding options.

Next, the highest ranked qualities among the group of positive psychological qualities chosen by the subjects were examined. The data in Figure 2 reveal that the highest percentages of key constructs were in positive psychology, such as "optimistic, fun, humorous", and "being helpful to others and bringing happiness and fun to others". Two constructs
Happy people: Who are they?

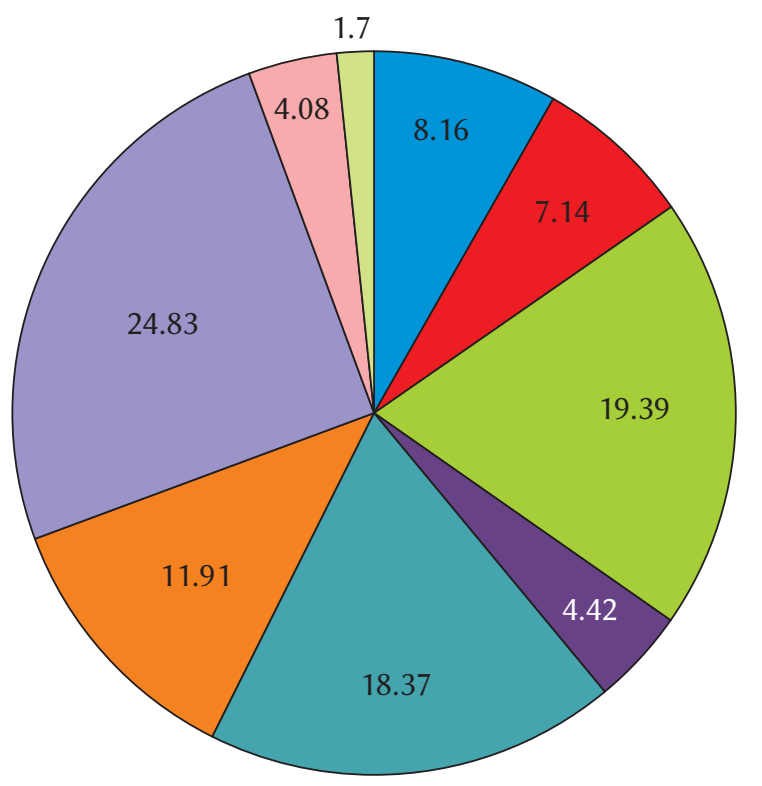

$\square$ Living conditions

Health and outlook

$\square$ Self-actualization

$\square$ Community belonging

$\square$ Social relationships

$\square$ Relationships with other family members

$\square$ Positive psychological qualities

$\square$ Personal safety

$\square$ Some other external factors

$N=58, N$ answers $=294$

Figure 1. Percentage distribution of components of happiness definition.

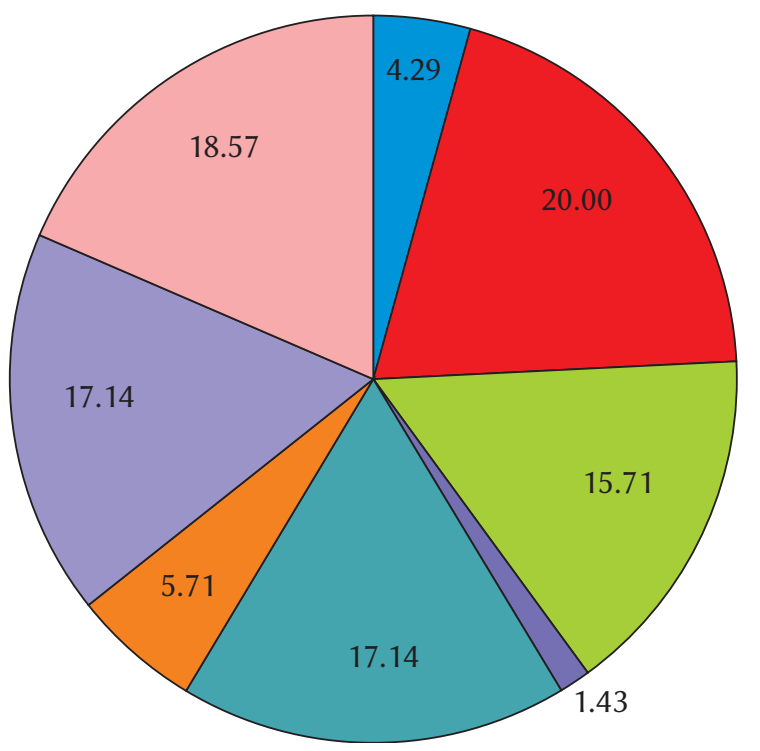

$\square$ Be honest, inclined to do good, empathetic

- Be optimistic, fun, humorous

$\square$ Be free-minded, simply thinking

$\square$ Be hard-working

$\square$ Be adaptive, unambitious, self-balanced

$\square$ Be independent

$\square$ Be aspirational

$\square$ Be helpful and bring happiness to the others

Figure 2. Percentage distribution of personal quality component of happiness definition. 
Linh Thi Trinh, Ha Truong Thi Khanh had the same percentage of responses (17.14\%): "being adaptive and self-balanced" and "being aspirational". The results of data analysis also illustrate that a happy person is someone who is "free-minded and simple thinking". Meanwhile, "be independent" or "hard-working" only contribute small proportions to happiness among respondents. It seems that in the Vietnamese perspective, positive characteristics play an extremely important role to establish a happy person.

This pilot study, apart from understanding the Vietnamese people's opinions about happiness, sought preliminary information about differences in the definition of happiness by gender, age, and educational level. However, statistical analysis did not allow us to record any statistically significant differences among participants, except the difference in positive psychological qualities by sex. Accordingly, the male participants tended to appreciate positive psychological qualities more than the females $\left(\chi^{2}=6.74, p_{\text {(Fisher test) }}=.015\right)$.

\section{DISCUSSION}

\section{THE COEXISTENCE OF INDIVIDUAL-ORIENTED AND SOCIAL-ORIENTED CONCEPTIONS OF HAPPINESS}

Answering the hard question of "What is happiness?" is unavoidable if we are to further our understanding of human happiness. With the aforesaid nine main factors listed as key traits of a happy person (see Table 1), the results of this pilot study demonstrate both similarities and differences of the Vietnamese definition of happiness with the results of other previous studies.

\section{Table 1}

Factors contributing to Vietnamese conception of happiness
1. Living conditions
2. Health and outlook
3. Self-actualization
4. Community belonging
5. Social relationships
6. Relationships with other family members
7. Positive psychological qualities
8. Personal safety
9. Some other external factors (encountering a surprise, being lucky, reading a funny story, etc.)

It is clear to see that the Vietnamese conception of happiness is closely similar to the roots of happiness expressed by Haybron (2013). This Vietnamese conception also appear to share certain similarities with the results of Delle Fave, Brdar, Freire, VellaBrodrick, and Wissing's research (2011) in which the authors found that family and social relations were prominently associated with happiness. Additionally, the personal accountability that appeared in Chinese subjective well-being of Lu's research $(2005,2012)$ also clearly manifests in the opinion of our Vietnamese participants. These results are also in line with the value orientation of Vietnamese people that Trần Ngọc Thêm noted in 2015. In their research, 5604 respondents from the north, middle and south of Vietnam, aged 15 to 74 , were asked to select the seven most important values from a list of 21 . The four most frequently selected values were (a) happiness in family life (82.93\%), (b) stable employment (75.47\%), (c) justice in society $(53.42 \%)$, and (d) wealth $(52.21 \%)$. All of these values were noted by our subjects when discussing happiness.

As a collectivist country, Vietnamese people attach great importance to social relations. Based on the results of in-depth interviews with our sample, it is clear that respondents placed a happy person inside very specific relationships (e.g., personal relationships with others, relationships with family members), and equally importantly, a happy person should feel like he or she is a member of the community (being recognized, respected, and loved by others). The following extracts from in-depth interviews illustrate this statement more clearly. For instance, the participants stated that a happy person "is loved by others", "attracts affection of others", "is loved and cared about by others", "has healthy parents and a happy family", "has the family by their side", "everybody in the family loves each other and lives in harmony", "has close friends who they can trust and share secrets with”. As Đỗ Long (2000) has pointed out, in traditional Vietnamese culture, individual identity is not seen separately, but is always examined in relation to a series of system relationships that each individual belongs to. Therefore, people often use "we/our" to replace "I/my" in everyday life (e.g. "To swim in our own pond, regardless of whether it is clear or shallow"). As stated by Marr (2000), the term "cá nhân" ("individuals" in English) is new to the Vietnamese language, and only appeared in approximately the last decade of the twentieth century.

It was also noted during in-depth interviews that apart from the emphasis on community belonging, the respondents also highlighted individual factors when the topic of happiness was under discussion. Accordingly, it was revealed a happy person not only possesses positive social relationships but also can actualize one's capacities and have positive psychological qualities. The consolidated data even al- 
low a conclusion that the individual is responsible for one's own happiness. Thus, it can be seen that an individual-oriented concept co-exists with the social-oriented one in the Vietnamese conception of happiness. This shows a difference from the former traditional Vietnamese image, particularly before the Vietnamese Renovation, in which collective ownership of means of production was central. As a result, self-expression was not common during that time. However, it is entirely similar to the results provided by Đỗ Long and Phan Thị Mai Hương (2002)'s studies on the community spirit of Vietnamese youngsters. These authors record that although the community spirit is distinguished among Vietnamese youngsters, the individual self has also been displayed relatively strongly. Put differently, Vietnamese youngsters seem to be in a transformational stage. During the open economy and international integration of Vietnam, they held traditional traits of the Vietnamese society and developed new qualities at the same time. As pointed out by Hofstede (2001), when the level of wealth within a country increases, the level of national individualism will rise. Lu $(2003,2005)$ also noted this tendency closely related to young Chinese people. Accordingly, the concept of self-composition was proposed by Lu to characterize an evolving selfsystem among contemporary Chinese people. This system of self-composition intricately integrates the traditional Chinese construct of "self-in-relation" (interdependence) with the Western construct of "independent and autonomous self" (independence). Therefore, the independent self may be nurtured, developed, elaborated, and even emphasized in certain domains of life. This trend is especially prominent among the young, the well-educated and urban people of China (Lu \& Kao, 2002). Therefore, as young people at their early adult stage, we think that it is understandable and reasonable for them to experience the co-existence of the social-oriented self and the individual-oriented self in defining happiness.

\section{BALANCED AND DIALECTICAL VIEW OF HAPPINESS}

Although in our study the self is displayed relatively strongly, it is not the narrow-minded and selfish individualism as confirmed by Đỗ Long and Phan Thị Mai Hương (2002). Therefore, though the participants highlighted the factor of aspiration in their definition of happiness, they also acknowledged that adaptation and harmonious homeostasis were equally important for the creation of happiness. For instance, some participants stated the following: "a happy person is one who can balance their life, because they will not be overloaded with work or become overwhelmed with negative consequences", "a person who always knows how to maintain inner peace", and "a person who knows the limit of enough". This was also found by Delle Fave and her colleagues (2011) in their study on happiness conducted with 666 participants in Australia, Croatia, Germany, Italy, Portugal, Spain, and South Africa. According to these authors, the term "harmonious homeostasis" reflects more specifically the perception of harmony at the inner level, as inner peace, self-acceptance, serenity, a feeling of balance and evenness that was best formalized by philosophical traditions in Asian cultures such as Vietnam. This concept of inner balance was confirmed previously in research with Chinese students by Lu $(2005,2012)$. This author even stated that this dialectical concept of balance on happiness was only displayed by the Chinese participants, and was nowhere to be found in the Americans' accounts of happiness.

This balanced and dialectical view of happiness is also proven true for participants who recognize happiness and unhappiness as two sides of the question. In their point of view, happiness and unhappiness are ever-present as the background to each other. For example, a happy person is "not an ill person", "not misunderstood by others", and "does not encounter troubles in life". According to this point of view, people should not aggressively strive for happiness to be happy. Instead, they should find inner peace and external harmony within themselves. This can come from the ancient philosophy of yin and yang, which states that everything from the universe to the life of a human being is a continuously changing process between good and the evil, happiness and pain, healthiness and diseases. As pointed out by Chenyang (2008), it refers to mixing different things and balancing opposite elements into a whole.

\section{CONCLUSIONS}

While most measurement instruments of happiness in the world are constructed in the form of scales mainly developed in countries such as European nations and America, the results of this research have contributed to confirming the validity of the qualitative approach in research on happiness. To date, this can be considered as the first study in Vietnam approaching happiness via a qualitative methodology with in-depth interviews, without using designated tool sets developed from international research. Because the results of in-depth interviews were not influenced by the researchers' opinions, the data obtained can be used as a scientific database for designing future measurement instruments of happiness specifically applied to the Vietnamese. While most qualitative research on happiness focuses on students (Lu, 2001, 2005; Pflug, 2009), which significantly affects the generalization of the research results, the access to the young at the early stage of adulthood has contributed to a wider view.
Happy people: Who are they? 


\section{LIMITATIONS}

The data presented in this paper are consolidated from responses of Vietnamese participants who are at an early stage of adulthood and selected via convenience sampling. Convenience sampling is a non-probabilistic technique where participants are selected because of their convenient accessibility and proximity to the researcher. Consequently, it is questionable to consider these samples as representatives of the Vietnamese at
Linh Thi Trinh, Ha Truong Thi Khanh this age range, who are not likely to be considered as representatives of the Vietnamese opinions about happiness in general. Besides, since the number of participants involved in this research is limited, one should be prudent in generalizing the research results. In addition, the participants, all of whom are working and living in Hanoi, Vietnam, are at certain educational levels (college or higher). These demographic variables may influence how individuals perceive and interpret the concept of happiness. As a result, application of the results to the Vietnamese in general requires more in-depth research on a larger scale with the following aims: 1) establish psychometric reliability and validity of the Vietnamese Happiness Scale indicated in this study; 2) investigate whether the Vietnamese scale of happiness is different from the already established "Individual-oriented and social-oriented cultural conceptions of subjective scales" (ISSWB) of Chinese happiness; and 3) investigate cultural and psychological correlations and predictors of happiness.

\section{References}

Andrews, F. M., \& Withey, S. B. (1976). Social indicators of well-being: America's perception of life quality. New York: Plenum Press.

Argyle, M. (2001). The psychology of happiness ( $2^{\text {nd }}$ ed.). London: Routledge.

Argyle, M., Martin, M., \& Crossland, J. (1989). Happiness as a function of personality and social encounters. In J. P. Forgas \& J. M. Innes (Eds.), Recent advances in social psychology: An inter-national perspective (pp. 189-203). North Holland: Elsevier

Braun, V., \& Clarke, V. (2006). Using thematic analysis in psychology. Qualitative Research in Psychology, 3, 77-101. https://doi.org/10.1191/1478088706qp063oa

Campbell, A., Converse, P. E., \& Rodgers, W. L. (1976). The quality of American life. New York: Russell Sage Foundation.

Chenyang, L. (2008). The ideal of harmony in ancient Chinese and Greek philosophy. Dao, 7, 81-98. https://doi.org/10.1007/s11712-008-9043-3

Christopher, C. (1999). Situating psychological wellbeing: Exploring the cultural roots of its theory and research. Journal of Counseling and Development, 77,141-152.https://doi.org/10.1002/j.1556-6676.1999. tb02434.x
Delle Fave, A., Brdar, I., Freire, T., Vella-Brodrick, D., \& Wissing, M. P. (2011). The eudaimonic and hedonic components of happiness: Qualitative and quantitative findings. Social Indicators Research, 100, 185-207. https://doi.org/10.1007/s11205-010-9632-5

Diener, E. (1984). Subjective well-being. Psychological Bulletin, 95, 542-575. https://doi.org/10.1037/00332909.95.3.542

Diener, E. (2000). Subjective well-being: The science of happiness and a proposal for a national index. American Psychologist, 55, 34-43. https://doi.org/ 10.1037/0003-066X.55.1.34

Diener, E. (2009). Assessing well-being: The collected works of Ed Diener. New York: Springer Science + Business Media.

Diener, E., Suh, E. M., Lucas, R. E., \& Smith, H. L. (1999). Subjective well-being: Three decades of progress. Psychological Bulletin, 125, 276-302. https://doi.org/10.1037/0033-2909.125.2.276

Diener, E., \& Tov, W. (2007). Subjective well-being and peace. Journal of Social Issues, 63, 421-440. https:// doi.org/10.1111/j.1540-4560.2007.00517.x

Denzin, N. K., \& Lincoln, Y. (2000). Handbook of qualitative research. Thousand Oaks, CA: Sage.

Dương Thi Thu Hương (2012). Các yếu tố tác động đến mức độ hài lòng về đời sống tinh thần [Factors affecting the level of satisfaction of spiritual life]. Xã hội học số, 4, 64-75.

Đỗ Long (2000). La formation du "moi” chez l'enfant Vietnamien sous l'influence de la culture [The formation of the "me" in the Vietnamese child under the influence of culture]. In O. Lescarret, K. Le, \& H. Ricaud (Eds.), Actes du colloque «Enfants, cultures, éducations» [Proceedings of the conference "Children, cultures, education"] (Vol. 1, pp. 191-195). Hanoi: Ed. du monde.

Đỗ Long, \& Phan Thị Mai Hương (Eds.) (2002). Tính cộng đồng - tính cá nhân và "cái tôi" của người Việt Nam hiện nay [Community - Individuality and the "self" of Vietnamese people today]. Hà Nội: Nhà xuất bản Chính trị quốc gia.

Frost, N. (2011). Qualitative research methods in Psychology: Combining core approaches. Berkshire: McGraw-Hill Education.

Glaser, B. G., \& Strauss, A. (1967). The discovery of grounded theory. Strategies for qualitative research. New York: Aldine.

Haybron, D. M. (2013). Happiness: A very short introduction. Oxford: Oxford University Press.

Hoàng Bá Thịnh (2012). Sự hài lòng về cuộc sống của người Việt Nam: Một số phát hiện ban đầu và hàm ý chính sách [Life satisfaction of Vietnamese people: Some initial findings and policy implications]. Tạp chí Nghiên cứu con người, 4, 3-13.

Hofstede, G. (2001). Culture's consequences: Comparing values, behaviors, institutions, and organizations across nations. London: Sage.

Kareem, J., \& Littlewood, R. (2000). Intercultural therapy. Oxford: Blackwell. 
Lê NgọcVăn (2018). Hạnh phúc của người Việt Nam: Quan niệm, thực trạng và chỉ số đánh giá [Happiness of Vietnamese people: Concepts, situation and indexes of evaluation]. Đề tài độc lập cấp quốc gia.

Lu, L. (2001). Understanding happiness: A look into the Chinese folk psychology. Journal of Happiness Studies, 2, 407-432. https://doi.org/10.1023/A:1013944228205

Lu, L. (2003). Defining the self-other relation: The emergence of a composite self. Indigenous Psychological Research in Chinese Societies, 20, 139-207.

Lu, L. (2005). In pursuit of happiness: The cultural psychological study of SWB. Chinese Journal of Psychology, 47, 99-112.

Lu, L. (2012). Chinese well-being. In H. Bond (Ed.), The Oxford Handbook of Chinese Psychology (pp. 327-342). New York: Oxford University Press.

Lu, L., \& Gilmour, R. (2006). Individual-oriented and social-oriented cultural conceptions of subjective well-being: Conceptual analysis and scale development. Asian Journal of Social Psychology, 9, 36-49. https://doi.org/10.1111/j.1467-839X.2006.00183.x

Lu, L., \& Kao, S. F. (2002). Traditional and modern characteristics across the generations: Similarities and discrepancies. Journal of Social Psychology, 142, 45-59. https://doi.org/10.1080/00224540209603884

Markus, H. R., \& Kitayama, S. (1991). Culture and the self: Implications for cognition, emotion, and motivation. Psychological Review, 98, 224-253. https://doi.org/10.1037/0033-295X.98.2.224

Markus, H. R., \& Kitayama, S. (1998). The cultural psychology of personality. Journal of Cross-Cultural Psychology, 29, 63-87. https://doi.org/10.1177/ 0022022198291004

Markussen, T., Fibæk, M., Tarp, F., \& Tuan, N. D. A. (2018). The Happy Farmer: Self-Employment and Subjective Well-Being in Rural Vietnam. Journal of Happiness Studies, 19, 1613-1636. https://doi. org/10.1007/s10902-017-9858-x

Marr, D. G. (2000). Concepts of "individual" and "self" in 20th century Vietnam. Modern Asian Studies, 34, 769-796. https://doi.org/10.1017/S0026749X00003851

Mashaba, G. (1996). The nurse, self and society: An introduction to applied behavioral sciences for nurse and health care professionals. Hongkong: Info Medical.

Nguyễn Thị VânHạnh (2013). Sự hài lòng về cuộc sống của người Việt $\mathrm{Nam}$ hiện nay xét trên góc độ nghề nghiệp, việc làm và mức sống [Life satisfaction of Vietnamese people today in terms of career, employment and living standards]. Tạp chí Khoa học ĐHQGHN, chuyên san Khoa học Xã hội và Nhân văn, 29, 10-18.

Nguyễn Tường Bách (2012). Hạnh phúc, quyền uy, lòng tham [Happiness, power, and greed]. In Câu chuyện phát triển và hạnh phúc [Story of development and happiness] (pp. 333-338). Hồ Chí Minh: Nhà xuất bảnTổng hợp thành phố Hồ Chí Minh.

Nguyễn Văn Thọ (2012). Phát triển và hạnh phúc [Development and happiness]. In Câu chuyện phát triển và hạnh phúc [Story of development and happiness] (pp. 66-71). Hồ Chí Minh: Nhà xuất bảnTổng hợp thành phố Hồ Chí Minh.

Nguyễn Văn Trọng (2012). Hiểu biết có mang lại hạnh phúc? [Does knowledge bring happiness?] In Câu chuyện phát triển và hạnh phúc [Story of development and happiness] (pp. 348-356). Hồ Chí Minh: Nhà xuất bảnTổng hợp thành phố Hồ Chí Minh.

Patton, M. Q. (1990). Qualitative evaluation and research methods. Thousand Oaks, CA: Sage.

Pflug, J. (2009). Folk theories of happiness: A cross-cultural comparison of conceptions of happiness in Germany and South Africa. Social Indicators Research, 92, 551-563. https://doi.org/10.1007/s11205-008-9306-8

Rogoza, R., Truong, T. K. H., Różycka-Tran, J., Piotrowski, J., Żemojtel-Piotrowska, M. (2018). Psychometric properties of the MHC-SF: An integration of the existing measurement approaches. Journal of Clinical Psychology, 74, 1742-1758. https://doi.org/10.1002/jclp.22626

Seligman, M., \& Csikszentmihalyi, M. (2000). Positive psychology: An introduction. American Psychologist, 55, 5-14. https://doi.org/10.1037/0003-066X.55.1.5

Selin, H., \& Davey, G. (Eds.). (2012). Happiness across cultures: Views of happiness and quality of life in non-Western cultures. Heidelberg: Springer.

Tafarodi, R. M., Lang, J. M., \& Smith, A. J. (1999). Self-esteem and the cultural trade-off: Evidence for the role of individualism-collectivism. Journal of Cross-Cultural Psychology, 30, 620-640. https:// doi.org/10.1177/0022022199030005004

Trần Ngọc Thêm. (2015). Một số vấn đề về hệ giá trị Việt Nam trong giai đoạn hiện nay [Some issues about Vietnamese value system in the present time]. Hồ Chí Minh: Nhà xuất bản Đại học Quốcgia Thành phố Hồ Chí Minh.

Triandis, H. C. (1994). Theoretical and methodological approaches to the study of collectivism and individualism. In U. Kim, H. C. Triandis, C. Kagitçibasi, S. Choi, \& G. Yoon (Eds.), Individualism and collectivism: Theory, method, and applications (pp. 41-51). Thousand Oaks, CA: Sage.

Triandis, H. C. (1995). Individualism and collectivism. Boulder, CO: Westview.

Uchida, Y., \& Ogihara, Y. (2012). Cultural construal of happiness: Cultural psychological perspectives and future direction of happiness research. Japanese Psychological Review, 55, 26-42. https://doi. org/10.24602/sjpr.55.1_26

Uchida, Y., Ronasakkunkit, V., \& Kitayama, S. (2004). Cultural constructions of happiness: Theory and empirical evidence. Journal of Happiness Studies, 5, 223-239. https://doi.org/10.1007/s10902-004-8785-9

Veenhoven, R. (1984). Conditions of happiness. Dordrecht: D. Reidel Publishing Company.

Veenhoven, R. (1994). Is happiness a trait? Tests of the theory that a better society does not make people any happier. Social Indicators Research, 32, 101-160. https://doi.org/10.1007/BF01078732

Veenhoven, R. (2003). Happiness. The Psychologist, 16, $128-129$.
Happy people: Who are they? 